\title{
THE ORGANIZATION AND METHODOLOGY OF A COMPREHENSIVE ANALYSIS OF LAND RESORUCES ON THE BASIS OF A BALANCE SYSTEM OF INDICATORS
}

\author{
Tetiana Bincharovska \\ Department of Accounting and Economic and Legal Security of Agriculture Business \\ Ternopil National Economic University \\ 11 Lvivska str., Ternopil, Ukraine, 46000 \\ tetianka11@ukr.net
}

\begin{abstract}
In Ukraine, land relations have been undergoing permanent reforming for more than twenty-five years. The transition period characterized by the events such as the abandonment of a command economy and the advent of a market economy has considerably affected the various aspects of land ownership and land use, starting with change in the form of land ownership and land resource distribution (reparcelling) and all the way up to attempts to develop a free market of agricultural lands. Nowadays, the use of land resources for agricultural purposes shows certain tendencies and particularities, which both heavily depend on and spring up due to the intensification of competition on the land rental market, an acute need for preserving soil and reviving its fertility, and the necessity to ensure rational and efficient use of agricultural lands.

Management decisions concerning each one of the domains aforementioned should be well-grounded considering external environment, market and internal economic status quo. Making this possible means developing a rational system to enable a comprehensive analysis of land resources with respect to all decision-making levels.
\end{abstract}

Keywords: land use, land resources, economic analysis, land relations, analysis of lands.

\section{Introduction}

The development of the comprehensive analysis of land resources has solid methodological basis, which is located in the crossing of various domains of scientific effort. However, a key obstacle hampering the development of an efficient and rational approach to using land resources for agricultural purposes has a comprehensive pattern and the most distinctive features of thereof are the absence of the accurate informational system of both research and the notification of the participants of land relations, the continuous transition of land relations to a shadow market and the absence of comprehensive system of economic analysis capable of providing management with relevant information in accordance with management and manufacturing purposes an enterprise engages in. Pursuant to this, it is reasonable to rest out views on the notion that "there is currently not any unified, self-sufficient and efficient approach to carrying out research in the use of land resources owned by commercial companies [1, p. 38].

The under-study problems addressing an analytical basis for the use of and making improvements into land utilization techniques applied by agriculture firms attribute to the matter of comprehensive land reforming. Pursuant to this, various aspects of such reforming can be analyzed and successfully addressed by means of specialized and inter-discipline approaches and tools. As a matter of a fact, the recent studies reflect fruitful findings on data needed to conduct a decent economic analysis on the use of land resources [2,3]. The qualitative features of under the crop areas have been comprehensively addressed by Ukrainian researchers, who have clearly described a cause-effect relationship between land under crop fertility and productivity per hectare [4]. Accounting and analytical features of land use constitutes an important aspect to consider while conducting economic analysis of land resources $[1,5]$. However, the recent studies have failed to adequately address efficient multi-indicator approaches to economic analysis of land resources

\section{Aim of research}

The aim of the research is development and grounding a unified methodological approach to composing a data bank for economic analysis of land resources and developing a comprehensive system of land use indicators. 


\section{Methodology}

To carry out this research study we have looked into views of pioneer economists addressing land resource analysis with an emphasis on agriculture firms. The toolkit used in this study includes customary methods of obtaining knowledge such as observation, analysis, synthesis, comparison, deduction and induction.

\section{Results}

Within the context of this research study, an analysis of economic phenomena is regarded neither as the scientific method nor the management function, but its essence becomes apparent by means of the process-based approach in accordance with which analysis of land resources owned by commercial agricultural firms is considered as "an objectively defined order of analytical procedures used to analyze data in order to obtain necessary information" [6, p. 52]. This definition paves the way for the development of the purpose of analysis, which is regarded as "increasing the level of credibility of decision-making and decreasing uncertainty while planning rational land use" [7, p. 165]. Along similar lines, the purpose of analysis of land resources consists in "utilizing lands form the perspective of supreme efficient and at full throttle, though keeping in mind the necessity of constantly boost fertility and preserve environmentally friendly economic activities. Developed recommendations based on the results of analysis should ensure full and efficient use of all lands despite purpose and extent of exploitation" [1, p. 39].

In accordance with the suggested views on the essence and purpose of the analysis of land resources it is recommended to define thereof as the rational sequence of accounting and analytical procedures regarding collection, processing and the utilization of data on the state of land resources and derivative processes. The rational sequence of procedures is designed to ameliorate the credibility of decision-making as to land use efficiency, preservation and the cultivation of the qualitative and quantitative parameters of land resources and ceaseless compliance with the principle of stability.

The suggested definition of one of the key types of research consists in the development and grounding of the unified methodological apparatus designed to assist a researcher in achieving certain goals and objectives such as the improvement of the credibility of decision-making, the preservation and amelioration of parameters and the compliance of the principle of stability and sustainability.

In the recent research studies the definition of methodology takes a shape as "the aggregation of means of and rules for researching economic processes attributing to an enterprise's activity that in a certain way intensifies the process of reaching the purpose of analysis" [6, p. 121].

Thus the methodological basis for both analysis and balancing a set of indications showing the state of land use suggested in this research study need comprehensive understanding of the object of research in all its dimensions. Scalene and multidimensional research on land resources paves the way for an opportunity to develop a new perspective in order to apprehend a problem. The basis of such methodology relies on accurate and clear identification and the structuration of a research object. In our case, the main category, which is land resources, should be viewed as a system from the following perspectives:

1. The object of turnover;

2. The object of use;

3. The object of management;

4. The object of economic regulation.

The structuration suggested above sheds light on domains and subdomains, which need further research and within the context of which there may be reserves or opportunities for making improvement into resources and the system of management approaches to allocating such resources. Furthermore, each of domains and subdomains should de detailed at the low level of knowledge. According to this, the purpose of land resource analysis needs scrupulous view in order to develop methodology in the form of clearly formed and structured objectives.

Pursuant to the definition of the land resource analysis suggested in this research study, the purpose of the under-research process expects the formation of a united apparatus for providing 
informational and analytical basis of decision-making in order to ameliorate credibility of decision-making as to land use efficiency, preservation and cultivation of the qualitative and quantitative parameters of land resources and ceaseless compliance with the principle of stability.

To achieve the purpose of research and find solutions to outlined problems, it is necessary to engage in well-developed system of activities, the most important aspect of which is the formation of a comprehensive system of indicators. The importance of the system-based feature within the context of this aspect consists in the interdependence between indications showing state and dynamics of economic processes and state that "specific data attributing to various types of activity should be organically entwined into a single comprehensive system" [6]. Additionally, it is also suggested that "the efficiency of land utilization cannot be characterized by a single indication, since the process of land utilization is multidimensional and depends on a number of factors of environmental and economic origin. To numerically show this relationship it takes to apply a multi-indicator approach" [3].

On the basis of the conducted analysis within the framework of this study and generalization it is found that there is not any unified approach to developing such system of indicators. In most of research studies there is little understanding of not only what a set of indicators should be like, but also classification and characteristics of thereof. On these grounds, a system of indicators is developed to analyze land resources formed according to extent to which they affect the object of the research (Fig. 1).

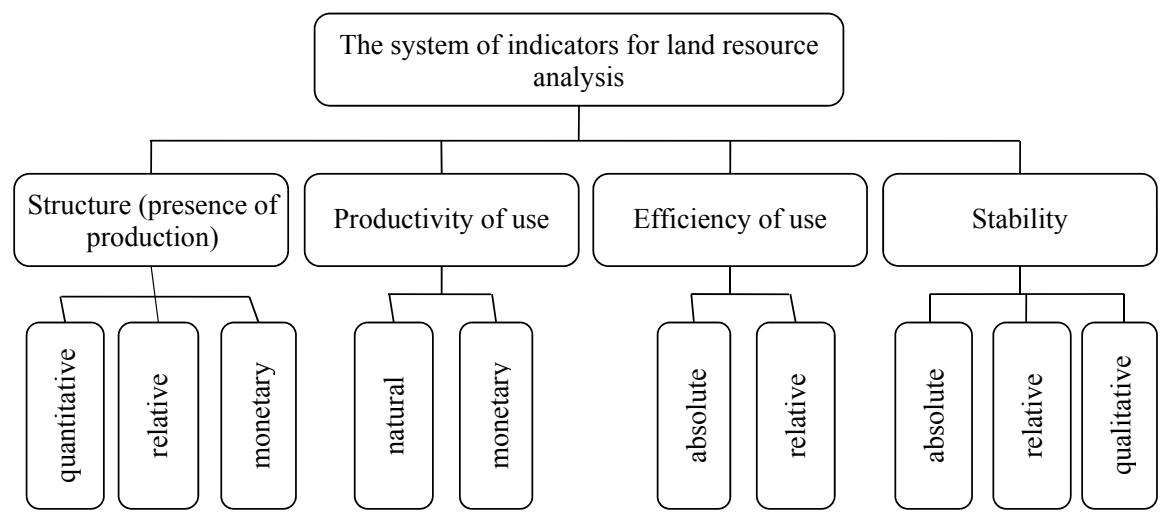

Fig. 1. The structure of indications for land resource analysis. Source: systemized by the author on the basis of $[8,12,11,10,13,14,6]$

The particularities of the methodology of indicator development outline the structuration of indicators. There is no denying that indicators of structure reveal the amount of land resources and their structure by various aspects in relation to a general level. At this point, they can take a shape of qualitative, quantitative and monetary indicators. This group of indicators to our opinion also contains the indicators of the intensity of land use and land provision. Productivity indicators means the comparison of results obtained in the process of the utilization of land resources and derivative costs an enterprise spends to finance the process. The indicators can be absolute and relative. The last group of indicators characterizes the stability of land use by providing data on ecological aspects, quality of soil and extent of rationality in land use. This group contains absolute, relative and qualitative indicators.

It is necessary to indicate that indicators of land use efficiency do not fall within separate categories in a number of research studies [7]. The amount of a crop gathered in a specific area under crop defines efficiency (for example, gross product per 100 hectares). Moreover, productivity is another signal of efficiency and features its relative measure [8]. In addition, they place an emphasis on the necessity to apply efficiency indicator in relation to resources, which are scares on the market. Pursuant to this distinguishing productivity and efficiency when referring to land use are suggested. Additionally, productivity should be regarded as the rate of land resource return per unit 
of area under crop, meanwhile efficiency should be the ratio of crop collected from the unit of area under crop to labor expenditures.

Complexity associated with economic analysis of land resources from the perspective of the single self-sufficient process of data collection requires accurate regulation and structuration. Pursuant to this, it is suggested to develop a clear step-by-step approach within the framework of analysis in order to conduct a more accurate and extensive research. The economic analysis theory offers the three stages of analysis: preliminary (preparative), body of analysis (data processing) and conclusive analysis (summary of results) [6, p. 122] (Fig. 2).

On the basis of the summarized findings, which derive from the recent research studies on land resources utilized by agricultural enterprises it is expanded and provided a better understanding of the separate stages of the economic analysis of land resources with the purpose of ensuring that analytical and management operations comply with logical sequence. It has enabled us to integrate operations into a single algorithm. It is necessary to mention that those operations are associated with data collection, processing and making recommendations on findings and further incorporate into an enterprise's activities.

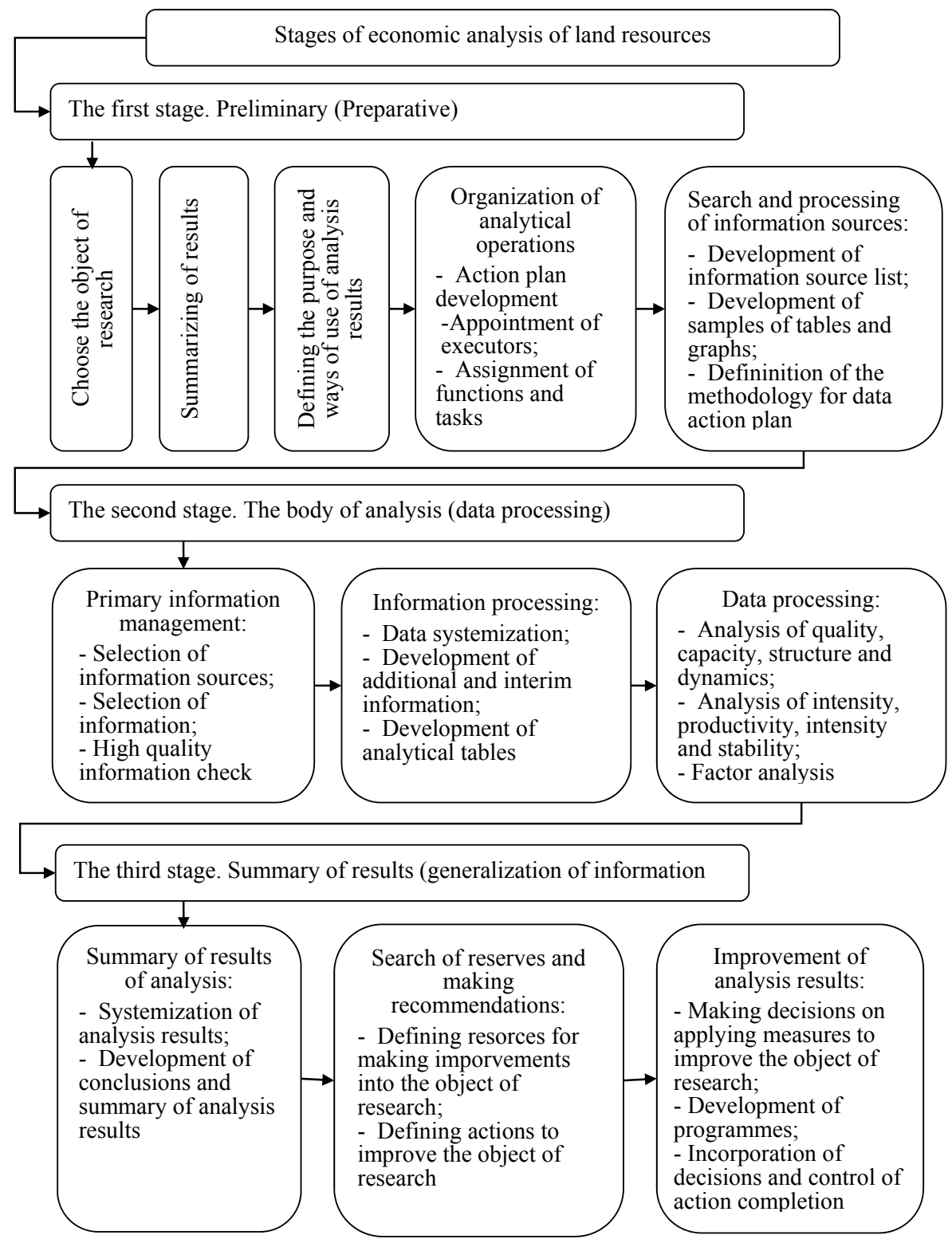

Fig. 2. The stages of land resource analysis in agricultural enterprise. Source: Improvement made by the author on the basis of $[4,5,10]$ 
The basis for sustaining efficiency of economic analysis is rational selection of information sources and forms regarding the state of land resources and related process and objects of research. Additionally, it is necessary to create a system of information flows by communication channels inside and outside of enterprise in accordance with functions and tasks assigned to employees.

The recent research studies offer various approaches to developing data base for land resource analysis. Furthermore, researches find the common ground when it comes to a claim that there is neither any unified form of report [9] nor a compromise agreement on data collection [1] that would outline the architecture of the activities of agriculture enterprises, give efficient indicators and provide with reasonable information on use of land resources.

Within this context, it is necessary to develop well-grounded basis for information supply [1]. At this point, it keeps in mind not only data on the state of land resources and derivative parameters, but also a single aggregation of data on the status of land resources (proprietary right, terms and conditions of use). Legislative acts of national and municipal levels, as well as primary legal documents regulating economic activities (rent agreements, transfer of property, buy-and-sell operations, enfeoffment, deeds of proprietary rights or right of use, court's decisions on proprietary rights and use of land resources; legal opinions and upshot of valuation or quality of land) represents initial information supply [9]. Information the sources of aforementioned contain makes a case for carrying out analysis, specifies conditions and should be considered in the process of conducting an analysis.

Among the already introduced information sources, which can be used for analysis of land resources pursuant to specified tasks and indicators, it is necessary to pay attention to the existence of significant differences in their classification. Pursuant to this, from the perspective of the extent of data processing there are primary, synthetic and analytical data. According to the nature and design of information there are data classified according to financial, management, statistical and business accounting. Without arousing a discussion, let's suggest combining the two approaches. Pursuant to this, each of types of accounting uses pertaining to it primary data and develop synthetic and analytic accounting rosters.

Analytical data on the state of land resources in the accounting system and reporting composed by agriculture enterprises is inadequately scarce. There is no denying that data on availability and amount of under-the-crop areas is located in the form of public statistical viewing (also known as the 50-th form) called as the Main Economic Indicators of the Activities of Agriculture Enterprises. The third section of the Form called Annual Land Use draws a special attention when it comes to data on availability and amount of under-the-crop areas. This section contains information on land under crop, including areas for rent. This section is filled in accordance to the Deed of right of land use, records in a land and cadastral journal, tenancy agreement for land under crop use and data on public land accounting [10, p. 79].

The 50-th form serves also as the source of other information necessary for land resource analysis. In particular, it contains data on manufacture results, the fields from where crop was collected; output; prime cost, as well as sales, including net sales, manufacturing and total cost price and net income.

The Paper 1 pertaining to the Form called the Breakdown of Manufacturing Cost Price by the Types of Agriculture Goods contains data on cost of seed stock used and other kind of stock for growth crop, as well as the amount of direct labor expenditures. The Manufacturing Expenditures on Agriculture Goods Section also contains information about the amount of rent paid on land shares. The Paper 2 contains information on the average number of employees involved in the agriculture industry by branches of industry.

While evaluating need for indicators designed to conduct a comprehensive and balanced land resource analysis the fact is pinpointed that there is not any unified accounting form required to acquire information about quality and state of soil, service expenditures on under the crop lands, economic evaluation of areas under crop and certain aspects of stability regarding land use. Some aspects of given information can be outlined by referring to data the land and cadaster journal contain. The journal branches into five sections: (1) distribution of lands by maturity, (2) the amount of lands and areas under crop, (3) the quality of areas under crop, (4) the indicators of the assessment 
of lands and (5) personal plots of land [11, p. 144]. However, such journals are either not kept nowadays or information they contain does not adequately reflect reality.

This is the reason why it is necessary to analyze land resources comprehensively. Moreover, let's suggest utilizing data deriving from management accounting, as well as from deeds of land evaluation by the State Institution "Soil Protection Institute of Ukraine" and reports of the State Land Cadaster of Ukraine.

Thus, it is plausible to state that accounting and informational aspects of land resource analysis are in need of improvement. The most problematic issues hamper the systemization of sources and channels of information acquirement. Moreover, it is necessary to develop clear procedures for data processing and facilitating following data management.

In general, means and methods of data acquirement and processing can be illustrated in the form of a table (Table 1).

According the Table 1, land resource analysis stands out by a self-sufficient methodological apparatus, which harmonizes stages of analytical activity (data acquirement, processing and analysis), sources and channels of information, and means and methods of analysis to obtain certain results. It is important to make scrupulous selection of approaches and analysis methods in order to ensure efficient analysis of land resources.

Table 1

Grouping of means and methods of data processing and land resource analysis

\begin{tabular}{|c|c|c|c|}
\hline Action & $\begin{array}{l}\text { Means and methods of data } \\
\text { acquirement and processing }\end{array}$ & $\begin{array}{l}\text { Means, channels and sources of } \\
\text { data acquirement }\end{array}$ & Results of analysis \\
\hline 胥 & Monitoring, observation and fixation & $\begin{array}{c}\text { Direct observation, primary } \\
\text { documentation, expert appraisal }\end{array}$ & $\begin{array}{c}\text { Data on state, quality and status of } \\
\text { land resources }\end{array}$ \\
\hline 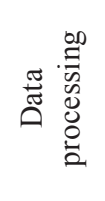 & $\begin{array}{l}\text { Comparison; structure analysis; } \\
\text { grouping; dynamics analysis; } \\
\text { detailing; graphic means; } \\
\text { index methods }\end{array}$ & $\begin{array}{c}\text { Accounting, statistical, financial } \\
\text { and operative records; synthetic and } \\
\text { analytical registers }\end{array}$ & $\begin{array}{l}\text { Finding of regularities, cause-effect } \\
\text { relationships, trends; systemization of } \\
\text { data on land resources; data visualiza- } \\
\text { tion; finding of index dependence of } \\
\text { land resources }\end{array}$ \\
\hline 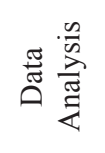 & $\begin{array}{l}\text { Statistical modeling, methods of } \\
\text { factor analysis, marginal analysis, } \\
\text { cost methods; optimization methods; } \\
\text { modelling methods }\end{array}$ & $\begin{array}{l}\text { Grouped and generalized data, } \\
\text { intermediate analytical data, data on } \\
\text { the state of production factors }\end{array}$ & $\begin{array}{c}\text { Mathematical models, forecasts, } \\
\text { generalization, factor dependence, } \\
\text { extent of potential, rate of return, } \\
\text { reserves }\end{array}$ \\
\hline
\end{tabular}

Source: systemized and improved by the author on the basis of [6, 12, 13, 14, 8, 15]

It takes efforts to apply the methods of land resource analysis described above, for there are a number of factors a researcher should take into account such as land location, land fertility, scarcity and fertility limits etc. Analytics should be scrupulous when developing a toolkit for research, since it should count particularities abovementioned in order to make reasonable and credible conclusions and recommendations for efficient land resource management.

\section{Discussion}

Our views completely harmonize with the notion that "there is currently not any unified, self-sufficient and efficient approach to carrying out research in the use of land resources owned by commercial companies. [1, p. 38].

The design of the purpose of land resources analysis is described by means of synthesizing the existing concepts of the essence and purpose of land resource analysis. However, the researchers whose studies are studied have different opinions. It is vital to apply means of "increasing the level of credibility of decision-making and decreasing uncertainty while planning rational land use" [7, p. 165]. Along similar lines, the purpose of analysis of land resources consists in "utilizing lands from the perspective of supreme efficiency and at full throttle, though keeping in mind the 
necessity of constantly boost fertility and preserve environmentally friendly economic activities. Recommendations developed based on the results of analysis should ensure full and efficient use of all lands despite purpose and extent of exploitation" [1, p. 39].

The importance of the system-based feature within the context of this aspect consists in the interdependence between indications showing state and dynamics of economic processes and state that "specific data attributing to various types of activity should be organically entwined into a single comprehensive system" [6]. Additionally, it is also suggested that "the efficiency of land utilization cannot be characterized by a single indication, since the process of land utilization is multidimensional and depends on a number of factors of environmental and economic origin. To numerically show this relationship it takes to apply a multi-indicator approach" [3]. There is a considerable difference in classification of prime data sources that can be used in economic analysis of land resources between that provided in the studies analyzed in this article and the suggested classification. It is argued that in accordance with data processing it is reasonable to define primary documents, synthetic and analytical data.

\section{Conclusions}

1. Land resource analysis is a must have of government to make efficient land reforms. Furthermore, a productive land resource analysis defines the extent to which agricultural firms benefit from their economic activities. Such analysis encloses various objects and objectives and it takes a comprehensive aggregation of indicators to disclose those objects and objectives to the fullest. One of the key tasks of a land resource analysis is to develop systems for automatic search, collection and processing of data, as well as developing mechanisms in order that automatically obtain final analytical reports in accordance with specific requests, positions and situations.

2. On the basis of the views of the essence and purpose of land resource analysis the definition of thereof is refined, suggesting that it is a rational sequence of accounting and analytical data on the state of land resources and corresponding processes designed to boost credibility of decision-making so that agricultural firms take full advantage of the land under crop they subdue and at the same time improve their qualitative and quantitative parameters.

3. Some stages of land resource analysis considering findings in the recent research studies are expanded and refined. The novelty of this paper consists in expanded, refined and made improvement into the stages of the land resource analysis designed for agriculture firms with the purpose to ensure logical sequence in analytical and management operations. It has enabled to integrate operations into a single algorithm. It is necessary to mention that those operations are associated with data collection, processing and making recommendations on findings and further incorporate into an enterprise's activities.

\section{References}

[1] Ostapchuk, T. P. Analitychne zabezpechennia operatsii z zemelnymy resursamy silskohospodarskoho pryznachennia. Available at: http://eztuir.ztu.edu.ua/jspui/bitstream/123456789/6302/1/166.pdf

[2] Andriichuk, V. H. (2013). Ekonomika pidpryiemstv ahropromyslovoho kompleksu [Economy of enterprises of the agro-industrial complex]. Kyiv: KNEU, 779.

[3] Hutorov, O. I. (2006). Otsinka zemelnykh resursiv ta efektyvnosti investytsii. Kharkiv: Kharkivskyi natsionalnyi ahrarnyi universytet, 370.

[4] Harazha, O. P. (2016). Vydy ta pokaznyky efektyvnosti vykorystannia silskohospodarskykh uhid v upravlinni zemelnymy resursamy Ukrainy. Ekonomika i suspilstvo [Economics and Society], 3, 52-60.

[5] Zhuk, V. M. (2011). Oblikovo-analitychne zabezpechennia zemelnykh vidnosyn. Ahroinkom, 7-9, 116-121.

[6] Andrieieva, H. I., Andrieieva, V. A. (2009). Orhanizatsiia i metodyka ekonomichnoho analizu. Sumy: DVNZ «UABS NBU», 353.

[7] Pantiukhova, A. V. (2015). Teoretychko-metodychni aspekty analizu vykorystannia zemelnykh resursiv silskohospodarskoho pryznachennia. Proceedings from Ukraine's Development Strategy: Economic and Humanitarian Dimensions. Kyiv: Inform-analit. Ahentstvo, 163-166. 
[8] Stoliarova, M. A., Zherdeeva, O. V. (2014). Metodycheskye aspekty effektyvnosty yspolzovanyia zemelnykh resursov selskokhoziaistvennoho naznachenyia. Nauchnyi zhurnal KubHAU [Scientific journal of KubSU], 96 (2). Available at: http://ej.kubagro.ru/2014/02/pdf/20.pdf

[9] Belinska, S. M. (2015). Teoretychni zasady bukhhalterskoho obliku zemli. Biznes-navihator [Business Navigator], 1 (36), 168-173.

[10] Kireitsev, H. H., Ivanishhenko, L. O.; Ghrevcov, V. D. (Ed.) (1987). Oblik osnovnykh zasobiv u silskohospodarskykh pidpryiemstvakh. Kyiv: Urozhai, 176.

[11] Kushnirenko, Iu. A. (2013). Oblik ta opodatkuvannia zemel silskohospodarskoho pryznachennia: kontseptualnyi pidkhid. Ahroinkom, 7, 76-80.

[12] Vinichenko, I. I., Soroka, Iu. O. (2015). Efektyvnist vykorystannia resursnoho potentsialu silskohospodarskykh pidpryiemstv. Investytsii: praktyka ta dosvid [Investments: practice and experience], $22,34-37$.

[13] Sakal, O. V. (2013). Oblik zemelnykh resursiv yak peredumova efektyvnoho zemelnoho administruvannia. Heodeziia, kartohrafiia i aerofotoznimannia [Geodesy, cartography and aerial photography], 77, 87-91.

[14] Belinska, S. M. (2015). Metodychni aspekty otsinky zemelnykh resursiv dlia tsilei bukhhalterskoho obliku. Efektyvna ekonomika [Effective economy], 3. Available at: http://www.economy.nayka.com. ua/?op=1\&z=3915

[15] Hulinchuk, R. M. (2015). Metodychni osnovy otsinky potentsialu ta efektyvnosti vykorystannia zemel silskohospodarskoho pryznachennia. Zbalansovane pryrodokorystuvannia [Balanced nature management], 2, 107-113.

\title{
INVESTIGATION OF CONDITIONS AND BENEFITS FOR UKRAINE IN THE TRANSITION OF ITS HOUSEHOLD IN THE RANK OF THE INTERNAL INVESTOR OF THE STATE
}

\author{
Yuliya Bondarenko \\ Department of Management of Organizations \\ Institute of Economics and Management \\ Lviv Polytechnic National University \\ 12 Bandera str., Lviv, Ukraine, 79013 \\ Yulia.Bond@gmail.com \\ Tetiana Kulinich \\ Department of Management of Organizations \\ Institute of Economics and Management \\ Lviv Polytechnic National University \\ 12 Bandera str., Lviv, Ukraine, 79013 \\ tculia@gmail.com
}

\footnotetext{
Abstract

In the article the place, role and functions of families (households) as economic subjects of the market system are clarified. The interrelation, interdependence of categories of "savings", "investments" and "consumption" is defined. The importance and location of the internal investor in the investment process at the macroeconomic level is proved. The algorithm for determining the level of aggregate income of a family necessary for transition to the rank of an internal investor of the state is presented. Parallels are drawn between the author's theoretical and methodical approach proposed in the article and between the theories (laws, models) of a number of well-known economists, such as E. Engel, M. Tugan-Baranovsky, J. Keynes, P. Samuelson and others. The features of practical definition of the minimum level of the aggregate income of a family and a household for savings and investments for Ukrainian realities are revealed. The current and desired operating conditions and the results of financial and economic development of each of the interested parties are considered. In particular, for the population it is shown how, based on its real income, to identify and plan expenditures in order to move to investments. In addition, it is investigated: first, what exactly is the real minimum level of income per month will allow one person or a family (of two, three, four people) to survive in the economic conditions that defined
} 